\title{
Prototype of a glass to administer liquid to newborns
}

\author{
Protótipo de copo para administrar líquidos a recém-nascidos \\ Prototipo de taza para administrar líquidos a recién nacidos
}

\begin{abstract}
Suzana Lopes de Melo $^{1}$, Luciano Borges Santiago ${ }^{1}$, Cristiane Faccio Gomes ${ }^{2}$, Ana Lúcia de Assis Simões ${ }^{1}$, Virgínia Resende Silva Weffort ${ }^{1}$
\end{abstract}

The aim of this study was to describe the evaluation of health professionals about a prototype glass to administer liquids to newborns. It was a descriptive, exploratory study, which was carried out at the maternity of a university hospital, in Uberaba, MG, Brazil. Semi-structured questionnaires were applied to 75 health professionals, after administering a glass of milk to newborns, in the months of July and August, 2011. Quantitative data were analyzed descriptively and subjected to qualitative content analysis, three categories emerged: positive aspects, with 269 of the register units; negative aspects, with 11 units and suggestions to improve the glass, with six. Statistical analysis showed that the concepts 'good' and 'excellent', related to the prototype glass, presented rates over $90 \%$. The perception of the participants demonstrated a positive evaluation of the prototype glass, which proved to be a practical tool, the design and safe material for the execution of the 'technique of the little glass'.

Descriptors: Newborn; Breast-feeding; Feeding and Cooking Apparatus; Breast-feeding; Patient Care Team.

O objetivo desse estudo foi descrever a avaliação dos profissionais de saúde sobre um protótipo de copo para administrar líquidos a recém-nascidos. Trata-se de estudo descritivo-exploratório, realizado na maternidade de um hospital universitário, em Uberaba, MG, Brasil. Questionários semiestruturados foram aplicados a 75 profissionais de saúde, após administrarem leite com o copo aos recém-nascidos, nos meses de julho e agosto de 2011. Os dados quantitativos foram analisados descritivamente e os qualitativos submetidos à análise de conteúdo, emergindo três categorias: aspectos positivos, com 269 unidades de registro; aspectos negativos, com 11 unidades e sugestões para melhoria do copo, com seis. A análise estatística evidenciou que conceitos 'bom' e 'ótimo', relacionados ao protótipo de copo, apresentaram índices acima de 90\%. A percepção dos participantes demonstrou uma avaliação positiva acerca do protótipo de copo, que demonstrou ser um utensílio prático, de design e material seguros para a realização da 'técnica do copinho'.

Descritores: Recém-Nascido; Utensílios de Alimentação e Culinária; Aleitamento Materno; Equipe de Assistência ao Paciente.

El objetivo del estudio fue describir la evaluación de profesionales de la salud a respecto de un prototipo de vaso para administrar líquidos a recién nacidos. Estudio descriptivo, exploratorio, realizado en la maternidad de un hospital universitario, Uberaba, MG, Brasil. Cuestionarios semiestructurados fueron aplicados a 75 profesionales, después de la administración de la leche en taza a recién nacidos, entre julio y agosto de 2011. Los datos cuantitativos fueron analizados descriptivamente y los cualitativos sometidos al análisis del contenido, donde emergieron tres categorías: aspectos positivos, con 269 unidades de registro; aspectos negativos, con 11 unidades y sugestiones para perfeccionamiento del vaso, con seis. El análisis estadística evidenció que los conceptos bueno y óptimo, relacionados con prototipo de taza, presentaron índices superiores a 90\%. La percepción de los participantes demostró opinión positiva acerca del prototipo del vaso, que resultó ser una herramienta práctica, de forma y material, para la realización de la 'técnica de la taza'.

Descriptores: Recién Nacidos; Utensilios de Comida y Culinaria; Lactancia Materna; Grupo de Atención al Paciente.

${ }^{1}$ Universidade Federal do Triângulo Mineiro, Uberaba, MG, Brazil.
${ }^{2}$ Centro Universitário de Maringá, Maringá, PR, Brazil.

Corresponding author: Ana Lúcia de Assis Simões

Rua Dona Nitinha, 181, Bairro Estados Unidos, Uberaba, MG, Brazil. CEP: 38017-300. E-mail: assisimoes@yahoo.com.br 


\section{Introduction}

The World Health Organization recommended the exclusive breast-feeding for 6 months being complemented until two years of age or more ${ }^{(1)}$ and in the cases in which breast-feeding was temporarily interrupted, the mother should not use a milk bottle, providing orientation to administer the milk with a glass $^{(2)}$. It is a noninvasive alternative method which allows the sensorial stimulation of the newborn, the control of the demand in each sucking or licking and the antero-posterior movements by raising the sides of the tongue, so that the liquid is not spilled through the labial commissures ${ }^{(3)}$.

So, feeding through a glass does not interfere in the mechanisms of suction and teaches the newborn to milk from the breast ${ }^{(3)}$. Therefore, it is the method suggested to feed, medicate and hydrate the newborns ${ }^{(2,4)}$.

Having a specific glass to administer liquids to newborns is important so that the caregivers will not use glasses designed for adults ${ }^{(5)}$ or any other artifact, a costume which has been used since the old ages, when they used horns, bowls, pots, cups and several objects adapted to feed the newborn ${ }^{(6)}$.

So, there is the evidence of the need to standardize a glass which respected the anatomic and functional characteristics of the newborn, it should be ergonomically correct to make the acceptation by the newborn easy and the handling of the glass by the caregiver in the administration of liquids, in order to reduce the difficulties in the execution of the technique, and also to avoid the disbelief and the resistance in administering milk with the glass by some health professionals, mothers and family members ${ }^{(5)}$.

Facing that, this research had as goal to describe the evaluation of the health professionals of a prototype of a glass specially designed to administer milk or other liquids to the newborn according to these variables: design, practicality and material of the glass. It is necessary to inform that the mentioned glass is in a process of trademark register, registered in the Instituto Nacional de Patentes e Inventos (National Institute of Marks and Inventions) under no. 420907381537/2009.

\section{Method}

It is a descriptive exploratory study with qualitative and quantitative approach elaborated in the maternity of the Federal University Hospital of the Triângulo Mineiro, chosen as field of study for not allowing the use of a milk bottle or pacifier in their routine assistance.

The population of the study was constituted by health professionals of the institution who worked in the maternity, a total of 75 health professionals. The following criteria were used: to be a health professional, to work in the maternity ward and to have administered milk to a newborn using a glass, at least once. It is necessary to clarify that the mentioned health team is constituted by doctors, nurses, audiologists, psychologists, physiotherapists, technicians and nursing assistants. No health professional was excluded; everyone who complied with the established criteria and accepted to participate were included in the research. To receive the milk administered by the health professional through the proposed glass, the newborn must have the company of his mother; he must have been born at the right time, with 24 hours or more of life, be healthy and active, and having been fed from 90 minutes to a maximum of 150 minutes of the previous feeding.

The data were collected in July and August, 2011. All the health professionals were previously contacted to schedule the procedure and clarify the objectives of the research. Then the data collection occurred through the application of the structured instrument composed of two sections: I. Social demographic and professional data; II. Evaluation of the prototype of the glass by the health professionals.

The making of the instrument was based on the selection, construction and fundament of the content and its validation was made by five multi- 
professionals judges with a Doctor or Master degrees and with practice in administering milk in the glass. The pilot study was made with five professionals of the Pediatric First Aid Post with the objective to verify the clarity and adequacy of the instrument.

The instrument was formed by a questionnaire with two open questions related to the opinion of the participant about the prototype of the glass, and twelve of multiple choice, directed to the opinion of the health professionals on its design, practicality and material, having the following options answer: indifferent, bad, regular, good and excellent. The professional must choose only one item as an answer. No numeric values were attributed to the questions once the indication referred to the understanding of each concept.

The prototype of the glass was made with transparent glass, with smooth edge, domed and turned to the outside, measuring $54 \mathrm{~mm}$ high, $54 \mathrm{~mm}$ of edge diameter, $38 \mathrm{~mm}$ of diameter at the bottom (outside) and $46 \mathrm{ml}$ of useful capacity.

The liquid to be administered (colostrum or milk) was measured in a syrinx and transferred to the prototype of the glass, after that, it was offered to the newborn by the professional. After the administration, the health professional answered the questionnaire and later on, deposited it in an urn which was opened only at the end of the research.

The answers to the open questions were submitted to the technique of the analysis which were cut in small segments, preserving only the real meaning expressed in the content of the messages, resulting in the units of register ${ }^{(7)}$. They totalized 286 units of register, distributed in three categories: positive aspects of the prototype of the glass, negative aspects of the prototype of the glass and suggestions to improve the glass.

As to the closed questions the statistical analysis was used, after the elaboration of a data bank in the Excel $^{\circledR}$, with typing by double entry for validation of the data. The analysis itself was made in the SPSS (Statistical Package for the Social Science), version
17.0, and the category variable was analyzed by simple frequency and contingent frequency, with indicators of central tendency (average and amplitude) and of variability (Standard deviation).

This research was approved by the Committees of Ethics and Research with Human beings of the Federal University of Triângulo Mineiro, MG, under legal opinion no. 1854/2011. The questionnaires were numbered at random from 01 to 75 and each professional identified as ' $\mathrm{P}$ ' following sequential numbers.

\section{Results}

75 (100\%) health professionals were female, with ages between 20 and 65 years. Among the patients, 39 (54.0\%) were between 20 and 39 years, and $33(45.1 \%)$ were between 40 and 65 years old.

From the participants, 40 (53.4\%) were Nursing Technicians, 16 (21.3\%) Nurses, 9 (12\%) Nursing Assistants and $10(13.3 \%)$ other professionals with university level (speech therapist, physiotherapist, pediatrician and psychologist). Most of them, 44 (58.71\%) had been graduated for more than four to seven years, 14 (18.7\%) from four to seven years, 15 (20.0\%) from one to three years and 2 (2.6\%) less than one year.

From the professionals, 31 (41.3\%) had more than seven years of experience in administing milk through the glass, 15 (20.0\%) had between four and seven years, $18(24.0 \%)$ from one to three years and $11(14.7 \%)$ less than one year.

Category 1: positive aspects of the prototype of the glass covered 269 units of register, which showed the acceptance of the glass by the health professionals. The fragments extracted from the reports of the participants highlighted positive points regarding the characteristics of the glass, such as its functionality, safety, easiness and confidence to the caregiver; possibility of fitting on the labial commissures; easiness of posture and tongue exercise of the newborn; transparency (which allows to visualize 
the position of the lip, tongue and milk, material (glass) and resistance (it does not break when the newborn presses it with hands). These features were also highlighted: The benefits provided by its smooth edge, domed and turned to the outside, diameter of the edge of the glass, its height and width, besides its contribution in order to make the lip stay outside during the applicability of the 'technique of the little glass'.

Results of quantitative analysis confirm the qualitative findings concerning the characteristics of the glass, when they show that the 'good' and 'excellent' concepts were more present, being considered positive aspects of the glass.

When investigating the design of the glass, the diameter of the edge is an outstanding feature as a positive aspect of the glass, as seen in nine units of register: it is bigger, that is why it covers the mouth of the newborn better (P.16). The diameter of the edge improves the visualization when offering the milk (P.20). This opinion was confirmed in the quantitative analysis, in which the concept of 'excellent' (n=52) and 'good' (n=18) were attributed for the diameter of the edge.

The edge of the glass, turned to the outside, had been mentioned in ten units of register, as follows: this glass has a differentiated edge (P.2). The edge turned to the outside provides better fitting in the corners of the mouth (P. 20). The edge turned to the outside makes the glass stay in the right position in the mouth of the newborn (P. 22). Among the aspects evaluated quantitatively, for this item, the concept 'excellent' is mentioned by 65 professionals and 'good' by 8 participants.

The feature smooth and domed edge of the prototype of the glass was accepted in 22 units of registers: I though the glass was excellent for having a smooth and domed edge (P.10). With these round edges is much safer (P.55). The edge of the glass is domed and this prevents from hurting the newborn's mouth (P.39). The quantitative analysis confirms the statement, once 64 participants classified it as 'excellent' and 10 as 'good'.

The dimensions of the glass, that is, the height and the width are outstanding features, as a positive aspect of the glass in three units of registers: Fine height and width (P.10). Concerning the height, it was evaluated as 'excellent' by 49 participants and as 'good' by 17 . As to the width, 48 participants reported 'excellent' and 22 'good'.

In the evaluation of practically, the easy way the glass fits in the mouth of the baby was a very well qualified feature, with 56 units of register, among the positive aspects of the prototype of the glass, shown as follows: This model fits the mouth (P.19). The glass fits very well the corner of the newborn's mouth (P.34). This item was also well accepted according to the quantitative approach, with 58 participants choosing the option 'excellent' and 15 'good' referring to the fitting.

As to the possibility of having the inferior lip turned to the outside, while the newborn is drinking the milk, there was only one unit of register: The edge turned to the outside makes the inferior also turn to the outside (P. 27). Quantitative findings show a high number of data with 57 'excellent' and 15 'good'.

As to the posture and the work of the tongue of the newborn during his feeding with the glass, there were 41 units of register, showing a positive aspect: The newborn makes movements with the mouth looking for his diet (P.06). The baby manages to get the milk with the tongue more easily (P.54). The little tongue slides better into the little glass (P.75). The closed question of this item was coherent with the qualitative approach, once 54 professionals analyzed it as 'excellent' and 20 as 'good'. It should be highlighted that that question was not answered by one of the professionals.

The glass provided security to the participants, during the technique of feeding the baby with a glass, there were 57 units of register in qualitative approach, which reveals the acceptance of the glass by the professionals, once it was the item of the open questions with more units of register. The glass offers reliability to the professional when providing the liquid diet (P.04). The differentiated edge allows to offer milk to the newborn more safely (P.25). It makes the technique more pleasant and easier (P.43). This datum was also confirmed with the high rate of positive aspects listed in closed questions of the 
Table 1 - Distribution of the evaluations of the health professionals regarding the questions: design, practicality and material of the prototype of the glass to administer the liquids to the newborn

\begin{tabular}{|c|c|c|c|c|c|c|}
\hline \multirow{2}{*}{ Requirements } & \multirow{2}{*}{ № of evaluations } & \multicolumn{5}{|c|}{ Classification } \\
\hline & & Indifferent (\%) & Bad (\%) & Regular (\%) & Good (\%) & Excellent (\%) \\
\hline \multicolumn{7}{|l|}{ Design } \\
\hline Diameter of the mouth & 75 & - & $1(1.3)$ & $4(5.4)$ & $18(24.0)$ & $52(69.3)$ \\
\hline Edge to the outside & 75 & - & - & $2(2.6)$ & $8(10.8)$ & $65(86.6)$ \\
\hline Smooth and domed edge & 75 & $1(1.3)$ & - & - & $10(13.3)$ & $64(85.4)$ \\
\hline Height & 74 & $3(4.1)$ & $1(1.3)$ & $4(5.4)$ & $17(23.0)$ & $49(66.2)$ \\
\hline Width & 75 & $2(2.6)$ & $1(1.3)$ & $2(2.6)$ & $22(29.4)$ & $48(64.1)$ \\
\hline Total & $374(100 \%)$ & $6(1.6)$ & $3(0.8)$ & $12(3.2)$ & $75(20.0)$ & $278(74.4)$ \\
\hline \multicolumn{7}{|l|}{ Practicality } \\
\hline Mouth fitting & 75 & - & $1(1.3)$ & $1(1.3)$ & $15(20.0)$ & $58(77.4)$ \\
\hline Position of the lip & 75 & - & - & $3(3.9)$ & $15(20.0)$ & $57(76.1)$ \\
\hline Posture of tongue & 74 & - & - & - & $20(27.0)$ & $54(73.0)$ \\
\hline Seg. of the professional & 74 & & $1(1.3)$ & - & $26(34.1)$ & $48(64.6)$ \\
\hline Total & $298(100 \%)$ & - & $2(0.6)$ & $4(1.2)$ & $76(25.4)$ & $217(72.8)$ \\
\hline \multicolumn{7}{|l|}{ Material } \\
\hline Glass & 73 & - & $1(1.4)$ & $3(4.2)$ & $22(30.1)$ & $47(64.3)$ \\
\hline Transparency & 73 & $1(1.4)$ & - & - & $7(9.6)$ & $65(89.0)$ \\
\hline Sterilizable & 75 & $1(1.3)$ & $2(2.6)$ & $3(3.9)$ & $13(17.4)$ & $56(74.8)$ \\
\hline Total & $221(100 \%)$ & $2(0.9)$ & $3(1.4)$ & $6(2.7)$ & $42(19.0)$ & $168(76.0)$ \\
\hline
\end{tabular}

security item, when 48 reported 'excellent' and 26 'good'.

As to the material of the object (glass) and its resistance, it was observed that 34 units of register showed these characteristics of the glass as favorable. It does not break when the baby squeezes it with his hands (P. 72). This glass is firm in managing it (P.73). The analysis of the closed questions confirms this reported opinion, once among the participants, 47 reported 'excellent' and 22 'good'. Two professionals did not answer this closed question.

An important feature which was highlighted regarding the prototype is that the glass is transparent, a variable which reached 35 units of register in the category positive aspects, which can be exemplified with these reports: Possibility to better observe the tongue and the inferior lip (P.17). It allows to clearly visualize the content being administrated and the position of the tongue of the newborn (P.19).
The fact that the glass is transparent, allows to see if the newborn is correctly drinking the milk (P.65). The quantitative findings showed that this attribute was evaluated as 'excellent' by 65 participants and as 'good' by 7. Two participants did not answer the question.

With 4 units of register, the fact that the glass is sterilized and has easy hygiene is a positive aspect of the prototype. In the words of the participants: It is excellent because it is made of glass (P.03). It can be sterilized (P.10). More hygienic (P.20). In this item the quantitative analysis was more blunt, 56 participants reported 'excellent' and 13 'good'.

Table 1 presents the evaluations of the participants concerning design, practicality and material of the prototype of the glass. From the five items of design: diameter of the mouth, edge to the outside, smooth and domed edge, height and width, the total evaluation of the items was 'excellent' (14.4\%). 
In the evaluation of practicality, the four items (mouth fitting, position of the lip, posture of the tongue and the security of the professional, had evaluations from bad to excellent, most of the evaluations reached the concept 'excellent' (72.8\%). As to the material in the 3 items evaluated, excellent (76.0\%) was highlighted.

Concerning category 2 , negative aspects of the prototype of the glass, there were 11 units of register, in which the health professionals reported aspects of the glass in study that showed their non-acceptance and preferred the disposable plastic glass: I do not agree that it can be reused, even if sterilized (P.34). Risk of cracking and breaking (P.49).

In category 3, suggestions to improve the prototype of the glass, there were 6 units of register: Suggestion to be graded (P.37). Making another one, smaller, to assist the premature newborns (P.33). Train the professionals, once in out institution, the team is very resistant to changes (P.16).

\section{Discussion}

The lack of a specific and adequate device to perform a certain nursing procedure can generate insecurity in the professionals who work with newborns ${ }^{(8)}$; and the insecurity of the caregiver can generate stress ${ }^{(9)}$. Such situation can be experienced by many professionals of health who have in their daily hospital activities, administering milk to the newborns with inadequate glasses ${ }^{(5)}$. Researches show that working with adequate and specific utensils for the age range established, promotes easiness, security and the expected results can be better ${ }^{(8-9)}$.

The 'technique of the little glass', is to respect the demand and the pace of the newborn, not putting the milk into his mouth when administering the liquid with the glass, he must drink or lick the milk with tongue through antero-posterior movements and through humping (raising the laterals) of the tongue so that the liquid does not go out of the mouth ${ }^{(3,10)}$.

The transparency of the glass makes the use of this technique easier once it allows viewing the procedure under several aspects: fitting of the glass in the labial commissures; positioning of the tip that must be reverted; movements of the tongue; position of the milk in the glass; observation of the pace of the newborn when drinking the milk and also visualizing the behavior of the child when licking from the glass ${ }^{(5)}$. So, the caregiver must respect the need of the newborn concerning the volume of milk wanted with the tip of his tongue, or when asked to rest, once the difference of being fed using a glass is that the newborn has the self-control of the intake ${ }^{(2-3)}$.

The resistance of the glass prevents the caregiver to modify the shape of the edge, which can happen with other types of materials, tapering it when it is squeezed with his fingers and it can even be broken by the newborn. Its resistance also allows the glass to firmly press the inside part of the lower lip, helping it to stay outside ${ }^{(11)}$. Otherwise, administering liquids with other non-specific glasses for such purpose, or designed to be used by adults, can cause disbelief and insecurity of the caregiver ${ }^{(8-9)}$.

One of the determinations of the national policy for products and services concerning health forbids the use of plastic utensils which have bisphenol $\mathrm{A}^{(12)}$ for infants. Under this perspective, the prototype of the glass under study satisfactorily complies with such recommendation and the needs of the caregivers.

The edge turned to the outside is the main difference in the model of the glass under study, for making the fitting in the labial commissures easy, for helping the lower lip to turn to the outside and stimulate the similarity of the mechanism of sucking of the newborn on the breast ${ }^{(5)}$.

It is observed that the edge of the glass turned to the outside touches the bottom of the mouth better and the lingual frenulum. There is literature description that the touch in this region stimulates the reflex of searching of the newborn more quickly, using the lip of his tongue ${ }^{(13)}$. Up to the present time, no reports in the literature were found concerning the dimensions of the glass used to administer liquids to the newborn.

The initiative to develop a specific glass to 
provide liquids to newborn, premature or not, occurred facing the need to standardize a glass that would respect the physiology and the anatomic features of the newborn, and it should also be ergonomically correct for the handling of the caregiver. This need was observed in researches to keep breastfeeding and provide an easy administration of liquids, even if the newborn became temporarily away from their mothers ${ }^{(2)}$.

It is outstanding that since 2,000 B.C. there have been reports on the search for utensils with adequate dimensions to feed infants and, also, the human being has developed several shapes and materials, including glass, which later were substituted by plastic milk bottles. A test made with a disposable glass of $50 \mathrm{ml}$, confirms that an inadequate model of glass can jeopardize the technique ${ }^{(14)}$.

The lower lip remaining outside and downwards during the administration of the milk by the participants is similar to the posture obtained during breastfeeding with the correct handling ${ }^{(15)}$.

A research shows that the lower lip must remain turned to the outside, supporting the glass during the ingestion of the milk ${ }^{(5)}$. In the inside of the lower lip and in the bottom of the mouth, there are tactile stimuli which induce the reflexes of search, indicating that, for a better acceptance by the newborn, the glass must be fitted on the inferior lip and under the tongue ${ }^{(11)}$.

As to the indication of capacitation, it is confirmed by the literature, when it indicates the trainings in the handling of maternal breastfeeding in the health institutions ${ }^{(16)}$ and in the use of the technique of the little glass both by health professionals as well as by the mothers, in order to increase the rates of exclusive breastfeeding ${ }^{(17)}$.

The prototype of the glass developed with glass, provides a surface without roughness, slots and porosity, thus providing easy sterilization and disinfection through boiling. In the process of sterilization, there is the destruction of micro-organisms ${ }^{(18)}$, so the glass can be re-used in health venues.
Facing the suggestion of making smaller glasses for premature newborns, it is foreseen that glasses with edges of smaller diameter do not fit the labial commissures and that a lower height can be difficult for the caregiver to hold it firmly; therefore the possibility of having a smaller glass for the newborn was excluded.

It is highlighted that to grade the glass with measures is necessary for its manufacturing in a large quantity, a fact which implies in the need of funds. For that, other measures can be planned, aiming at obtaining conditions for its making and stimulus to its institutionalization as a utensil when the alternative feeding for the newborn is essential.

\section{Conclusion}

There was a positive evaluation concerning the prototype of the glass under study, considering its specific characteristics: design (diameter of the edge, height and width), material (transparent glass), the edge turned to the outside, smoothed and domed. Such features provide the fitting in the labial commissures, help the lower lip to have an inverted position and the stimulate the reflex for the tongue to get the milk from the glass faster, thus becoming the 'technique of the little glass', a breastfeeding learning for the baby.

Another important aspect to be highlighted was the perception of the feeling of security, easiness and reliability reported by the participants provided by the use of the prototype of the glass. For the health professionals, the possibility of acquiring adequate resources to do their work, promotes satisfaction, security and tranquility, which can even generate the feeling of pleasure for the work done. Adding to that, there is participation of the caregivers to the method of feeding the infant using the glass.

The use of the glass is suggested in situations where breastfeeding is temporarily interrupted. Besides that, the results of this work can awake in other professionals and caregivers who have not yet joined the 'method of the little glass', the interest to 
administer milk to a newborn, premature or not, using a glass, specifically developed for such purpose, which stimulates the reflexes to get the milk and the suction for a better fitting in the mouth of the newborn, through the posture and work of the tongue.

The glass showed to be a utensil with safe material, shape and dimensions for the health of the newborn, specific and adequate for the newborn and which is adapted to his oral cavity, it brings interest to new tests, including premature newborns and with specific difficulty of suction, or babies of mother with seropositive retroviruses. And it can also contribute to promote the participation of health professionals and institutions, and it can be and adopted by caregivers, nurseries, hospitals, the national net of milk bank, teams of family health and other related services.

\section{Collaborations}

Melo SL participated in the conception of the work, and in the collection, analysis and interpretation of the data, until the final writing of the work. Santiago LB contributed in the conception and final revision of the article; Gomes CF contributed in the methodological matters and revision. Simões ALA and Weffort VRS participated in the conception of the project, contributed in the data analysis and in the final revision of the version to be published.

\section{References}

1. Craig PL, Knight J, Comino E., Webster V, Pulver LJ, Harris E. Initiation and duration of breastfeeding in an aboriginal community in South Western Sidney. J Hum Lact. 2011; 27(3):250-61.

2. Ministério da Saúde (BR). Secretaria de Atenção à Saúde, Departamento de Atenção Básica. Saúde da criança: nutrição infantil: aleitamento materno e alimentação complementar. Brasília: Ministério da Saúde; 2009.

3. Menino AP, Sakima PRT, Santiago LB, Lamounier JA. Atividade muscular em diferentes métodos de alimentação do recém nascido e sua influência no desenvolvimento da face. Rev Med Minas Gerais. 2009; 19(4 Supl 5):11-8.

4. Medeiros AMC, Bernardi AT. Feeding preterm infants: breast, cup and bottle. Rev Soc Bras Fonoaudiol. 2011; 16(1):73-9.

5. Galego PAR, Gomes CF. O uso do copo na alimentação de lactentes: existe um modelo ideal? Temas Desenvolv. 2013; 19(104):73-6.

6. Castilho SD, Barros AA Fil, Cocetti M. Historical evolution of utensils used to feed non breastfed infants. Ciênc Saúde Coletiva. 2010; 15(Suppl.1):1401-10.

7. Bardin L. Análise de conteúdo. 5aㅡ ed. Lisboa: Ed.70; 2010.

8. Santos TCMM, Faria AL, Barbosa GES, Almeida PAT, Carvalho P. Intensive care unit: stressing factors in the nursing staff perception. Rev Enferm UFPE On Line [periódico na Internet]. 2011; 5(1):207. Available from: http://www.revista.ufpe.br/ revistaenfermagem/index.php/revista/article/ viewArticle/1158

9. Lelis ALPA, Farias LM, Rebouças CBA, Cardoso MVLML. Health promotion and nurse facing newborn pain in the neonatal unit: an exploratorydescriptive study. Online Braz J Nurs [periódico na Internet]. 2010;9(2). Available from: http://www. objnursing.uff.br/index.php/nursing/article/ view/j.1676-4285.2010.2996/699

10. Calado DFB, Souza R. Intervenção fonoaudiológica em recém-nascido pré-termo: estimulação oromotora e sucção não-nutritiva. Rev CEFAC. 2012; 14(1):176-81.

11. Burgemeister A, Sebastião LT. Neonatal ICU's professionals and the use of the cup to feed newborns. Distúrb Comun. 2013; 25(3):430-9.

12. Ministério da Saúde (BR). Agência Nacional de Vigilância Sanitária. Resolução RDC no 41, de 16 de setembro de 2011. Dispõe sobre a proibição de uso de bisfenol A em mamadeiras destinadas a alimentação de lactentes e dão outras providencias. [Internet]. Brasília, 2011. Disponível em: http:// www.sgc.goias.gov.br/upload/links/arq_304_ RDCANA41-2011-AUSOADEABISFENOLAA.pdf

13. Valério KD, Araújo CMT, Coutinho SB. Influência da disfunção oral do neonato a termo sobre o início da lactação. Rev CEFAC. 2010; 12(3):1-13. 
14. Silva ACMG, Alencar KPC, Rodrigues LCB, Perillo VCA. A alimentação do prematuro por meio do copo. Rev Soc Bras Fonoaudiol. 2009; 14(3):38793.

15. Silva IMD, Silva KV, Leal LP, Javorski M. Técnica da amamentação: preparo das nutrizes atendidas num hospital escola, Recife-PE. Rev Rene. 2011; 12(n. esp.):1021-7.

16. Graça LCC, Figueiredo MCB, Conceição MTCC. Contributions of the nursing intervention in primary healthcare for the promotion of breastfeeding. Rev Latino-Am Enfermagem. 2011; 19(2):1-9.

17. Lopes CLBC, Graziano KU, Pinto TJA. Evaluation of single-use reprocessed laparoscopic instrument sterilization. Rev Latino-Am Enfermagem. 2011; 19(2):370-7.

18. Melo LM, Machado MMT, Leite AJM, Rolim KMC. Preterm infant: maternal experience during breastfeeding in neonatal intensive care unit and after discharge. Rev Rene. 2013; 14(3):512-20. 